\author{
Alona SHYBA, \\ orcid.org/0000-0002-7533-4780 \\ Candidate of Pedagogical Sciences, \\ Associate Professor at the Department of English \\ Yuri Fedkovych Chernivtsi National University \\ (Chernivtsi,Ukraine) a.shyba@chnu.edu.ua
}

\title{
ASSERTIVENESS IN THE PROCESS OF STUDENTS' FOREIGN LANGUAGE COMMUNICATIVE COMPETENCE FORMATION
}

The article deals with the study of main factors influencing students'foreign language communicative competence formation. The author clarifies the definition of the notion "communicative competence" and its structure. The ways of a native language acquisition and of a foreign language learning are compared. The stages of the foreign language learning taxonomy are also named.

The main purpose of the given paper was to analyze the factors which influence foreign language communicative competence formation, single out the main personality factors and study the impact of interactive methods on students' assertiveness in the process of communication. To achieve the set tasks the following theoretical and empirical methods were used: analysis, synthesis, comparison, classification and pedagogical observation.

As the researches show student's readiness to communicate depends on how competent and relaxed the speaker feels about the target language, so it's important to develop students'fluency in a target language taking into account the affective factor. The affective factor has a great impact on the process of foreign language learning and that of the communicative competence development. The main personality factors - self-esteem, risk-taking, motivation, anxiety and inhibition - are analyzed in the article. Assertiveness is important for building a healthy self-esteem; it covers three concepts - confidence, tolerance and responsibility. An assertive person is calm, relaxed, confident and can clearly explain his/her viewpoint, knows how to recognize manipulation and protect himself/herself from it. As some students display higher readiness to communicate than others, some possible fears were singled out. To overcome obstacles which hamper students' communicative competence development the author suggests the usage of interactive methods, such as discussions, debates, case study, role-playing and simulations. Interactive classroom atmosphere boosts students' assertiveness, increases their readiness to participate in communicative acts and thus, develops their communicative competence.

Key words: competence, communicative competence, affective factors, assertiveness.

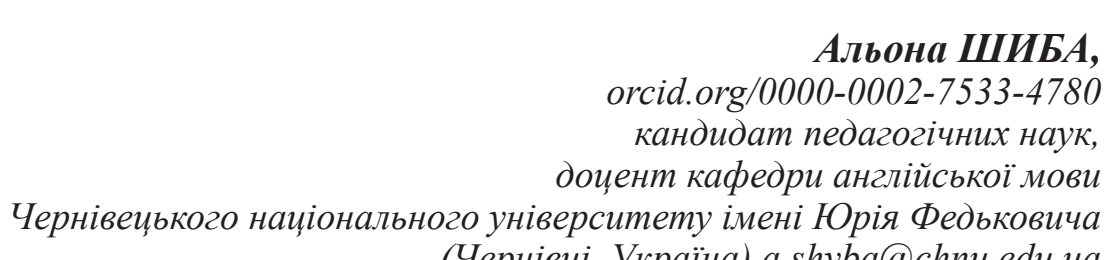

(Чернівиі, Україна) a.shyba@chnu.edu.ua

\section{АСЕРТИВНІСТЬ У ПРОЦЕСІ ФОРМУВАННЯ ІНШОМОВНӦ̈ КОМУНІКАТИВНОЇ КОМПЕТЕНТНОСТІ СТУДЕНТІВ}

Статтю присвячено вивченню основних чинників, щуо впливають на формування іншомовної комунікативної компетентності студентів. Авторка уточнює поняття «комунікативна компетентність» та ї структуру; порівнюються шляхи засвоєння рідної та іноземної мов. Основною метою даної роботи було проаналізувати чинники, щзо впливають на формування іншомовної комунікативної компетентності, виокремити основні особистісні фактори та визначити вплив інтерактивних методів на асертивність студентів у процесі спілкування. Для досягнення поставлених завдань застосовано низку теоретичних та емпіричних методів, таких як аналіз, синтез, порівняння, класифікація та педагогічне спостереження.

Оскільки готовність студента до спілкування залежить від того, наскільки добре мовеиь володіє іноземною мовою та наскільки він почувається спокійним та розслабленим, то навчання іноземній мові слід здійснювати $з$ обов 'язковим урахуванням афективного чинника. Даний чинник має суттєвий вплив на прочес вивчення іноземної мови та розвиток комунікативної компетентності. Асертивність важлива для формування здорової самооиінки; вона охоплює три поняття: впевненість, толерантність та відповідальність. Асертивна людина спокійна, розслаблена, впевнена в собі і може чітко пояснити свою точку зору, знає, як розпізнати маніпуляцію та захиститися від неї. Оскільки деякі студенти виявляють вищу готовність до спілкування, ніж інші, виділено деякі 
можливі причини иъьому. Для подолання перешкод, щчо заважають розвитку комунікативної компетентності мовців, авторка пропонує використовувати інтерактивні методи, такі як дискусії, дебати, кейс-метод, рольова гра тощзо. Інтерактивна атмосфера в класі підвищує асертивність студентів та їх активність у спілкуванні іноземною мовою, а отюе, розвиває їхню комунікативну компетентність.

Ключові слова: компетентність, комунікативна компетентність, афективні фактори, асертивність.

Introduction. The current stage of development of the educational system in Ukraine is characterized by the search of new ways and approaches to teaching. Special attention is paid to teaching foreign languages, as due to nowadays global changes in the world, professional and cultural ties of Ukraine with foreign countries the need for experts with a high mastery of foreign languages became obvious. The final and utmost goal of foreign language teaching and learning is the ability of the learner to use the language correctly and appropriately for a communicative purpose. Thus, the question how to help students improve their communicative competence arises.

The term "communicative competence" and the ways to develop it have been an object of investigation of a great number of scientists, among them D. Hymes, N. Chomsky, M.A.K. Halliday, M. Canale and M. Swain, B. Carroll, R. Gardner, P. Ur, A. Doff, H.D. Brown, J. Harmer, V. Cook, S.J. Savignon, etc. L. Vygotsky, S. Krashen, O. Lozova, I. Zymnia viewed the psychological aspects of foreign language learning, but the question of assertiveness in this process needs more detailed study.

The purpose of the given paper is to study the influence of students' assertiveness on the effectiveness of their communicative competence formation. To conduct the research a number of methods have been used: analysis, synthesis, comparison, classification, pedagogical observation and questionnaire.

Discussion. A competence - is a complex phenomenon, understood as a "combination of knowledge, skills, understanding, values, attitudes and desire which lead to effective, embodied human action in the world, in a particular domain" (Deakin, 2008: 38). As to the communicative competence the term has come to be used in language teaching contexts to refer to the "ability to convey meaning, to successfully combine a knowledge of linguistic and sociolinguistic rules in communicative interactions" (Savignon, 1983: 5).

Studying the components of the communicative competence, D. Hymes in 1967 mentioned linguistic and sociolinguistic ones, M. Canale and M. Swain in 1980 singled out grammatical, strategic and sociolinguistic competences and in $1983 \mathrm{M}$. Canale wrote about one more component - discourse competence. It was in 1995 when M. Celce-Murcia depicted the structure of communicative competence in a form of a pyramid with the following components: linguistic, actional, discourse, and sociocultural competence at the top (Celce-Murcia, 1995).

But when it comes to practice each teacher has to decide which approach or method to choose and which factors to take into consideration to help students develop all the components of the communicative competence and become fluent users of a target language.

Trying to answer this question we addressed certain psychological and linguistic theories concerning the question 'how a language is learned'. The scientific literature survey showed that the three main hypotheses of how a language is learned are viewed from the behaviourist, innatist and interactionist / developmental perspectives.

According to behaviourist hypothesis kids acquire language by imitating it until they form habits of correct language use. Children's language behavior depends on the quality and quantity of the language a child is exposed to. The representatives of the innatist theory believe that a child is biologically programmed for language development and speaking surrounding is just a subsidiary condition. The developmental theory describes the connection of a child's cognitive development and his/her language use. Though different in some aspects, these three theories have one thing in common: language development only occurs as a result of social interaction (Lightbown, 2017).

Still, acquiring a mother tongue and learning a foreign language is not the same. And if we compare second language learning to the first language acquisition, there are some factors that make this process easier and some - make it more complicated. As to the advantages - here we can mention cognitive maturity which develops mainly with older learners and thus makes the process of language learning easier in the way, the learners already have the idea how the language "works". On the other hand kids spend much more time listening to and acquiring L1, while L2 is in most cases learned in the classroom a couple of hours a week. Thus, to make the process of language learning more natural the student must have the possibility to regularly participate in meaningful communications.

Speculating about the stages through which the learner has to go in order to be fluent in a foreign language R. Valette suggests the following taxonomy:

1. Mechanical skills (it's the stage, where students' rote memory prevails) 
2. Knowledge (it's the stage on which students possess some knowledge about the way the foreign language functions)

3. Transfer (the stage presupposes application of acquired knowledge in new contexts)

4. Communication (on this phase of learning the student uses the foreign language for an effective communication).

5. Criticism (the student is able to analyze the foreign language, conduct a research) (Valette, 1977: 28).

As seen from the taxonomy above, to reach the level of an effective communication, the learner has to do a lot of drilling first, gain some knowledge about the ways a new language is functioning and have a lot of language and speech practice.

While teaching we noticed that some students more freely participate in classroom communication which helps develop their communicative competence quicker, while others are afraid to take risk at communication and prefer to stay aside, though their knowledge of the language may be higher. A wellknown American scientist S. Krashen singles out the following hypotheses concerning the process of a second language learning: the acquisition-learning hypothesis; the monitor hypothesis (monitoring the utterance which leads to accuracy of speech); the input hypothesis (receiving foreign language input one step higher than students' current level); the natural order hypothesis (sequence of grammatical structures); the affective filter hypothesis.

All the hypotheses are equally important and give results if implemented together. In this work we'll study the role of the affective factor on the efficiency of foreign language communicative competence formation.

S. Krashen names the following affective factors which are of a big concern in the process of foreign language learning: self-esteem, risk-taking, motivation, anxiety and inhibition (Krashen, 1981). Let's dwell on them in details.

Any cognitive activity can hardly be carried out successfully without some degree of self-confidence. It's not only about study but about every aspect of human life where self-esteem is important. And though it is hard to say whether self-esteem influences success in language learning or vice versa, the connection between them, as well as the importance to work on both is evident.

The process of new knowledge acquisition or skill formation can never be deprived of making mistakes. It's typical for foreign language learning and when it's easier with young learners who are always curios, emotionally active and are not afraid to make mistakes, with adolescents and adults it's quite different.
Teenagers though socially active, with higher cognitive abilities, suffer their self-confidence lowering. So anxiety and inhibition can also be typical in foreign language learning as it's natural for a person to feel self-doubt or worry in a new situation or to build a "defense wall" against something unfamiliar. Excessive anxiety, as well as inhibiting learning hamper the process of language acquisition. It's very important that an educator creates the positive classroom environment where students can feel at ease.

Inhibition is closely connected with risk-taking. Foreign language learning, especially at the beginning, is almost impossible without making mistakes, and students should not fear making them but rather take risk and speak, which is the only way to make progress in FLL. Students with a high self-esteem are more eager to take risk in the academic process.

The role of motivation in the process of foreign language learning can hardly be overestimated, be it the student's motivation with which he/she comes to school, or classroom motivational strategies which teachers apply during classes. Every person's activity is stipulated by some need and to fulfil it one should have a motive, which concerns a number of various psychological phenomena - pleasure, desire, reward, fear, intention, etc., which determine human activity.

The goal of the learner determines the type of motivation - intrinsic or extrinsic. If the goal of the learner is to study in order to get a positive grade or to please the parents, or to improve one's career, then it means that extrinsic type prevails. Intrinsic motivation is revealed when the student is stimulated to learn by his desire to improve his knowledge, and to become a well-educated person. Therefore, intrinsic motivation means that a person's motivational stimuli are coming from within, while extrinsic motivation takes place when motivational stimuli are coming from the outside. Though any motivation is good, we must admit that an intrinsic type of motivation is especially important for the long time goals in FLL. R. Gardner also describes two kinds of motivation learners can possess: instrumental (when FL becomes an "instrument" for achieving practical students' goals like higher grades or search for better career opportunities) and integrative motivation, when the student is stipulated to acquire FL to become a part of a new culture (Gardner, 1985).

M. Patsy names the following crucial individual differences that influence student's success in FLL: intelligence, language learning aptitude, learning styles, personality, attitudes, motivation, identity and ethnic groups affiliation and learner beliefs. The methodologist accepts that everyone has experienced occasions of avoiding communicating in a foreign 
language. "Willingness to communicate may change with the number of people present, the topic of conversation, the formality of the circumstances, and even with whether we feel tired or energetic at a given moment (Lightbown, 2017: 86).

Without any doubt there isn't but one factor important in the process of FLL, they all intervene and work together. Moreover it's not an easy task to measure and decide which of them contributes most to the student's language development.

The research carried out by Richard Clément, Peter Maclntyre, and their colleagues, proves that learners are willing to communicate due to their communicative confidence which is stipulated by two factors: how relaxed L2 learners are and how competent (or incompetent) they feel about their L2 ability. These factors are considered to be the main contributors to communicative confidence and are directly influenced by previous contacts with L2 speakers (Clément, 2003) and by how assertive the learner feels.

Assertiveness in terms of foreign language teaching is understood as an important psychological mechanism necessary for the implementation of effective interactive activities for the formation of students' communicative competence. This concept, though comparatively new in a scientific psychological literature, has already attracted researchers' attention, both psychologists and educators. Assertiveness is defined as "the quality of being confident and not frightened to say what you want or believe" (Cambridge dictionary), while the adjective assertive means "behaving in a confident way in which you are quick to express your opinions and feelings" (Macmillan dictionary). Having analyzed scientific literature on the given topic, we noticed that the term has acquired a bit broader meaning covering three concepts - confidence, tolerance and responsibility.

An assertive person behaves the way he/she considers to be right and feels personal responsibility for all his/her own actions. But at the same time, an assertive student displays respect to other members of the academic process, not suppressing his/her own interests.

An assertive behavior can be described as that of a self-confident person, when the needs and rights of others are respected, provided that others respect his rights. Assertive behavior is clear, straightforward; it is characterized by calmness, a person seems relaxedthat is both his verbal and nonverbal manifestations are not characterized by any tension. A person who behaves assertively is able to clearly articulate the essence of the interaction, how he/she sees the situation, what the expectations are, knows how to recognize manipulation and protect himself from it. Such a person has a positive attitude towards other people, is able to listen to other people's ideas and is not afraid to change his/her point of view under the influence of arguments. An assertive person is not ashamed to ask for assistance and is also always ready to help (Lvov, 2002). Assertive behavior can also help improve student's self-esteem.

Our teaching practice showed that only a few students, future English language teachers, fully display assertive behavior. Some of them seem embarrassed, don't eagerly participate in discussions or answer teacher's question, even if they know the answer perfectly well. To explain the reasons of students' self-doubt we addressed the work of F. Davis, who connects such a state with the presence of certain permanent fears: fear of being isolated, ostracism; fear of losing individuality, of being oppressed by others; fear of losing control; fear of seeming incompetent (Davis, 1996).

We paid considerable attention to overcoming these students' problems, as being assertive is extremely important not only in the process of learning, but also in their further teaching career. The appropriate use of interactive learning technologies, especially those involving group work, public speaking greatly contributed to the development of students' confidence and their readiness to interact in a foreign language. The implementation of discussions, debates, case study, role-playing and simulations, as well as the use of a number of Internet technologies both helped students better develop their fluency in a target language and motivated them to become active participants of the study process. Observations proved that natural and friendly interactive language learning atmosphere created favorable conditions to raise students' self-esteem and motivation, stimulated them to assertive behavior which lowered their anxiety. Thus, students' readiness to participate in communicative acts began to increase, which led to the communicative competence development.

Conclusions. So, students' assertiveness helps reduce stress and inhibition, boosters their self-confidence; readiness to communicate is increased. The implementation of interactive methods in the process of foreign language learning and teaching creates favorable conditions for making the process as natural as possible. Besides, an interactive atmosphere in the classroom increases motivation and students' assertiveness, which makes the process of students' communicative competence formation much more effective. Future investigations will be dedicated to the study of the influence of remote teaching and learning on students' assertiveness. 


\section{BIBLIOGRAPHY}

1. Deakin Crick, Ruth. Pedagogy for citizenship. Getting involved: Global citizenship development and sources of moral values / Ed. F. Oser \& W. Veugelers. Rotterdam: Sense Publishers, 2008. P. 31 - 55.

2. Sandra J. Savignon. Communicative competence: theory and classroom practice: Addison-Wesley Publishing Company, 1983. $340 \mathrm{p}$.

3. Celce-Murcia, M., Dornyei, Z., Thurrell, S. Communicative Competence: A pedagogically motivated model with content specifications, Issues in applied linguistics. 1995. 6 (2). URL: https://escholarship.org/uc/item/2928w4zj\#page-1.

4. Lightbown, P. M., Spada N. How languages are learned: Oxford University Press, 2017, 261 pp.

5. Valette R. Modern language testing (2nd edition): Harcourt Brace Jovanovich. 2-nd edition, 1977.337 pp. URL: https://archive.org/details/modernlanguagete00rebe/page/n1/mode/2up

6. Krashen S. D. Second language acquisition and second language learning: Pergamon Press Inc, 1981.150 pp.

7. Gardner, Robert. C. Social psychology and second language learning: the role of attitudes and motivation: Edward Arnold Ltd., 1985. URL: https://files.eric.ed.gov/fulltext/ED262624.pdf

8. Clément, R., Baker, S. C., Maclntyre, P. D. 2003. Willingness to communicate in a second language: The effects of context, norms, and vitality. Journal of Language and Social Psychology, 2003. P. 190 - 209.

9. Cambridge dictionary URL: https://dictionary.cambridge.org/dictionary/english/assertivenes.

10. Macmillan dictionary URL: https:/www.macmillandictionary.com/dictionary/british/assertive?q=assertiveness\#asse rtive 4 .

11. Львов В. М., Ильина А. В., Шлыкова Н. Л. К проблеме оценки и формирования ассертивности личности. Медиичиская психология. URL: http://ledleds.ru/?K_PROBLEME_OCENKI_I_FORMIROVANIYa_ASSERTIVNOSTI_ LIChNOSTI.

12. Девис Ф. Полная уверенность в себе. Исчерпывающее руководство на пути достижения личного успеха и уверенности в себе. Минск, 1996. 350 с.

\section{REFERENCES}

1. Deakin Crick, Ruth. (2008). Pedagogy for citizenship. Getting involved: Global citizenship development and sources of moral values. (Ed. F. Oser \& W. Veugelers. Rotterdam): Sense Publishers. [in English].

2. Sandra J. Savignon. (1984). Communicative competence: theory and classroom practice: Addison-Wesley Publishing Company. [in English].

3. Celce-Murcia, M., Dornyei, Z., Thurrell, S. (1995). Communicative Competence: A pedagogically motivated model with content specifications, Issues in applied linguistics. 6 (2). https://escholarship.org/uc/item/2928w4zj\#page-1. [in English].

4. Lightbown, P. M., Spada N. (2017). How languages are learned: Oxford University Press. [in English].

5. Valette R. (1977). Modern language testing (2nd edition). Harcourt Brace Jovanovich. [in English].

6. Krashen, S. D. (1981). Second language acquisition and second language learning, Pergamon Press Inc. [in English].

7. Gardner, Robert. C. (1985). Social psychology and second language learning: the role of attitudes and motivation. Edward Arnold (Publishers) Ltd. [in English].

8. Clément, R., Baker, S. C., Maclntyre, P. D. (2003). Willingness to communicate in a second language: The effects of context, norms, and vitality. Journal of Language and Social Psychology, 22 (2). [in English].

9. Cambridge dictionary. https://dictionary.cambridge.org/dictionary/english/assertivenes. [in English].

10. Macmillan dictionary. https://www.macmillandictionary.com/dictionary/british/assertive?q=assertiveness\#assert ive_4. [in English].

11. Lvov, V., Iliyna, A., Shlykova, N. (2002). K probleme otsenki i formirovaniia assertivnosti lichnosti [To the problem of assessment and formation of person's assertiveness]. Medical Psychology. http://ledleds.ru/?K_PROBLEME_OCENKI_I FORMIROVANIYa_ASSERTIVNOSTI_LIChNOSTI [in Russian].

12. Davis, Ph. (1996).Polnaya uverennost'v sebe. Ischerpyvayushchee rukovodstvo na puti dostizheniya lichnogo uspekha I uverenosti v sebe [ Total self-confidence. Ultimate guide on the way to achieving personal success and self-confidence]. Minsk [in Russian]. 